\title{
Imaginative construction of care: the nursing professional experience in a remote care service
}

\author{
Yocelyn Margaret Price Romero ${ }^{1}$ \\ Margareth Angelo ${ }^{2}$ \\ Luz Angelica Muñoz Gonzalez ${ }^{3}$
}

The direction of care delivery goes from the action to the being; a process built from professional experience, which gains special characteristics when the service is delivered by telephone. The goal of this research was to understand the interaction between professionals and users in a remote care service; to do so, a research is presented, using Grounded Theory and Symbolic Interactionism as theoretical references. Data were collected through eight interviews with professionals who deliver care by telephone. The theoretical understanding permitted the creation of the theoretical model of the Imaginative Construction of Care, which shows the interaction processes the professional experiences when delivering care by telephone. In this model, individual and social facts are added, showing the link between the concepts, with special emphasis on uncertainty, sensitivity and professional responsibility, as essential components of this experience.

Descriptors: Telenursing; Delivery of Health Care; Qualitative Research; Nursing.

\footnotetext{
${ }^{1}$ PhD, Assistant Professor, Facultad de Enfermería, Universidad Andrés Bello, Chile.

2 PhD, Full Profesor, Escola de Enfermagem, Universidade de São Paulo, Brazil.

${ }^{3}$ PhD, Full Professor, Facultad de Enfermería, Universidad Andrés Bello, Chile.
} 


\title{
A construção imaginativa de cuidados: a experiência de profissionais de enfermagem em um serviço de assistência remota
}

Prestar cuidados em saúde é questão que transcorre desde a ação até o ser; é um processo construído na experiência profissional e contém características especiais, ao ser realizado por meio de telefone. $\mathrm{O}$ objetivo deste estudo foi compreender a experiência de interação entre profissionais de um serviço de assistência remota, por telefone, com os usuários. Foi conduzido segundo a Teoria Fundamentada, tendo o Interacionismo Simbólico como referencial teórico. A coleta de dados foi realizada por meio de entrevistas com oito profissionais de enfermagem que prestam cuidados pelo telefone. A compreensão teórica resultante da análise interpretativa permitiu a construção do modelo teórico da Construção Imaginativa do Cuidado, que reflete os processos interacionais que o profissional vivencia quando presta cuidados por meio do telefone. O modelo incorpora fenômenos individuais e sociais, demonstrando a vinculação entre conceitos e destacando a incerteza, a sensibilidade e a responsabilidade do profissional como componentes essenciais da experiência.

Descritores: Tele-enfermagem; Assistência à Saúde; Pesquisa Qualitativa; Enfermagem.

\section{La construcción imaginativa del cuidado: la experiencia del profesional de enfermería en un servicio de asistencia remota}

\begin{abstract}
Brindar cuidados es una cuestión que transcurre desde la acción hasta el ser; un proceso construido desde la experiencia profesional, que cobra características especiales al ser brindado a través del teléfono. El objetivo de este estudio fue comprender la experiencia de interacción de los profesionales y los usuarios en un servicio de asistencia remota; para ello, se presenta una investigación utilizando la metodología de la Teoría Fundamentada y el Interaccionismo Simbólico como referente teórico. La recolección de datos se realizó mediante ocho entrevistas a profesionales que brindan atención telefónica. La comprensión teórica permitió la construcción del modelo teórico de la Construcción Imaginativa del Cuidado, el cual refleja los procesos interaccionales que experiencia el profesional cuando brinda cuidados a través del teléfono. En el modelo se incorporan los fenómenos individuales y sociales, demostrando la vinculación entre sus conceptos y destacando la incertidumbre, la sensibilidad y la responsabilidad del profesional como componentes esenciales de la experiencia.
\end{abstract}

Descriptores: Teleenfermería; Prestación de Asistencia de Salud; Investigación Cualitativa; Enfermería.

\section{Introduction}

Health systems are organized in different ways to attend to the population's needs. For this purpose, multiple health care strategies have been implemented, whose development sometimes demands the incorporation of different technologies. These range from diagnosis, treatment and information system technologies to the education of future professionals. On the other hand, health policies face the challenge of maintaining and strengthening humanized care. Also, the incorporation of new strategies and technologies has influenced professional nursing practice, as it involves facing new care scenarios, especially related to telemedicine, a condition in which professionals do not meet with users at any time.

In 2005, the Chilean Ministry of Health put in practice a Remote Care service by telephone, in view of international experiences aimed at offering support and permanent monitoring systems to citizens. All of 
this serves to make citizens feel protected, informed about their rights and equipped for decision making on their lifestyle and health maintenance, protection and recovery ${ }^{(1)}$. This telephone care system offers 24hour coverage across the country, with comprehensive information, education, decision-making support, care process monitoring and easy user-system interaction, without the need for transportation. The Salud Responde service aims to attend the entire population and to solve any health problem. Medical, nursing and midwifery professionals work at this service, who face the challenge of telephone care every day, in which faces and physical contact with people no longer exist. It is in nursing and midwifery professionals' care that most of the users' needs are solved, using their own knowledge and skills, incorporating the use of clinical guidelines and information technologies as work tools. Literature reports on the results of similar telephone support programs. Telephone use for health care delivery is a growing reality in the global context, because it improves access to health care information and reduces the costs of unnecessary health service visits $^{(2-7)}$. In this new context, the need emerges to study the challenges of professional communication related to remote care services and the way interaction between professionals and users is established by phone with a view to care delivery. In this professional care form, the understanding of communication processes can provide evidence for nurses' recycling and training, aiming to improve the care delivered to service users.

The objectives of this study were to: understand the experience of interaction between the nursing professionals and users of this remote care service and describe nursing professionals' intervention process and actions in view of users' needs.

\section{Methods}

Symbolic Interactionism was used as the theoretical framework, which explores how people define reality and how their definitions relate to their actions. The symbolic meanings ${ }^{(8)}$ serve as the base for interaction; they are individual and, in a social perspective, shared by groups. As the methodological framework, Grounded Theory was used, which advances in problem-solving related to people's active understanding and intends to produce a theory ${ }^{(9)}$, deriving from data that were systematically collected and analyzed through a research process. The participants were health professionals, nurses and midwifes, who had been working at Salud Responde for more than six months and had a total professional experience of at least five years, accepted to participate in the interviews and gave their consent. The study received previous approval from a research ethics committee, in compliance with legal standards (Law $20.120)^{(10)}$. Thus, the professionals received previous information about the study aims, the voluntary nature of their participation and their freedom to drop out of the study at any time without any need for justification. To determine the number of interviews, Theoretical Sampling(9) was used. This consists in data collection guided by the concepts deriving from the theory under construction, based on constant data comparison. This approach resulted in a convenience sample of eight professionals, out of 32 professionals working in this function during the data collection period. Participants were five nurses and three midwifes, including one man and seven women, who had been working at the service for between six months and five years and had graduated between four and 25 years earlier. Their other work areas were teaching, primary care, hospitalization and emergency care. Semistructured qualitative interviews were held and each interview took between 45 and 120 minutes. The guiding questions were: When did you start to work in Salud Responde?; How did you start to work in Salud Responde?; Why did you start to work in Salud Responde?; What is it like for you to develop your professional know-how in Salud Responde?; What do you believe results from this service for the families? How do you believe the families perceive this service?. Moreover: Tell me about a situation in Salud Responde that represents this experience according to you; How do you consider care is established in this situation?; Could you describe how you interacted with users in this experience?. Data(9) were analyzed through Open Coding, which implies the selection and naming of the data analysis categories. Then, Selective Coding was accomplished, in which the codes are more focused, selective and conceptual than those produced in the first phase. In Axial Coding, all data are reoriented through a paradigm code. Finally, Theoretical Coding involves the selection and identification of the central category and the systematic relation with other categories, with a view to the development of a theoretical model.

\section{Results}

\section{A different form of care delivery}

The start of the care delivery experience in Salud Responde is the entry into a process characterized by 
uncertainty. As a cognitive phenomenon, this conditions the development of communication with the user. Thus, professionals get mobilized for unknown work, in which the entry into Salud Responde occurs as a natural insertion in any kind of work. The attraction was the information, the way of delivering information, of collaborating before the people get to an emergency or primary care service, this thing of being able to advise people on what to do, it's fabulous. (E1)

Thus, they are being confronted with the uncertainty of work, an idea that is modified over time while they explore the situation; the uncertainty is delimited and defined, but at the same time incorporated as a part of the experience. Well, that's what happened at first, that we got nervous, the telephone rang and you didn't know what you were going to find on the other side. (E7)

The professionals build an image of work in Salud Responde, about the care delivery experience, without the physical space. A new perspective on care, the service, themselves and the users: At first I found it very hard, because I couldn't coordinate everything at the same time, either I talked or wrote on the computer, and then I got the other call and I couldn't finish. (E5)

\section{Care delivery to people through telephone care}

After characterizing and contextualizing the work, the professionals gradually unveil skills for care delivery, gaining and recognizing tools and personal and professional skills. In this perspective, uncertainty is understood as something positive, which implies a state of alert in the professionals: You learn to talk again, to express yourself so that they understand you on the other side without seeing you. (E3)

The professionals seek forms of learning to deliver care in Salud Responde, identifying the skills needed and how to develop them. Thus, they start to perceive the evolution in the way they develop their work: I believe the experience got richer as you incorporated your own knowledge and managed to master the system. (E3)

\section{Constructing interaction with the user}

The construction of interaction with users is a continuous and distinguishing development process, characterized by permanent creative processes in the imagination of different components that facilitate interaction. Professionals establish the context of the interaction as they incorporate elements available in their professional and personal experience into Salud Responde, through imaginative processes that permit the abstraction and incorporation of the experience into the new scenarios faced in each call. You imagine the people and they almost immediately become near, as you have to imagine. (E2)

The professionals construct the image of the user's reality; in this process, the space in which these two actors meet is recognized, characterized as a psychological space. I immediately tried to imagine what the person is like, and when they tell you, look, I'm in a rural area, I imagine what it's like to try and leave home. (E2)

In the same sense, they develop the interaction with the user, which emerges in this new context, where an image of the context and the user him/herself replaces the physical space. In other words, the physical space is lost, but one works with other spaces, the emotional space, the psychological space, which one can also lose sometimes when only doing physical things, but here the psychological space is developed much more. (E1)

Then, Becoming present for the user refers to the development of interaction with the receiver, when the roles and positions the distinct actors play in its development are defined, constituting a common interaction space, which is seen as a possibility to construct an abstract reality, based on the interaction between imaginative skills and a more concrete reality. I believe the presential part is much more influential in this sense, the non-verbal language can say much more than one wants to express, so you can express what you want to say better by telephone, the dialogue becomes cleaner. (E5)

Thus, professionals become capable of interpreting the user's signs, to the extent that they start to develop sensitivity, which permits the interpretation of users' different signs. The sense and the knowledge, understanding the phenomena that happen in human nature. (E2)

As the manner in which they develop their knowhow changes, characterized by sensitivity and good contact with users, a new way of being professional is constructed. We gained security, of course, I noticed that in the form, in the form of the answer we gave. (E1)

Professionals enhance the interaction, in the sense that interaction is simultaneously established with users and other professionals. There's also the interaction with the team, they're always beside you, suddenly one didn't look aside anymore and the other understood that and became alert, that is, it's collaborative and that makes it fun. (E2)

\section{Strengthening care}

Professionals acknowledge their development of sensitivity towards users. They permanently seek the continuity of care as a complementary aim, being there for the families who face difficult times, trying to 
approach the users and their care network and other support networks. Thus, an attitude, knowledge is transferred about what to do at a given time. (E4)

In the same sense, taking responsibility for the care delivered is a process in which professionals find themselves driven to get mobilized, to go beyond mechanically answering the call, in a unique individual action. I believe that we have to give concrete answers to concrete questions. We have to go beyond though, because our work is not just to answer the problem at that moment. (E6)

This strengthens care in the family, supporting the users' decisions, beyond technical aspects, through advice or simply by transmitting tranquility. We can clearly support decisions or provide clear indications, which the person may even have managed, but he wasn't that aware of it. (E6)

\section{The reality constructed in the interaction}

After characterizing the experience and experiencing the interaction with the user, the actors' intersubjectivity is revealed, which then provokes the construction of a social reality.

In Feeling the impact of the professional's response, the major influence is related to work itself, acknowledging the care delivered as a positive social value for the user. Perhaps some live in places far from health centers, where the only form of access to advice is by telephone. (E2)
Thus, the professionals understand the meaning of Salud Responde for users when considering the influence of this care in the population. For some it's a lifeguard, for others their only form of access to health, and still others see it as company, support. (E3)

Finally, the context is reconstructed, when the service is seen as an alliance between skills and knowledge, in which technology permits putting these at the user's disposal. But your intervention produced something, you talk to him and transfer a responsibility, and this person understands that this action will generate a change in his health situation. (E1)

\section{The Theoretical Model}

The theoretical understanding results from the analysis and interpretation of the conceptual categories that were constructed and the interrelations among them, permitting the construction and development of the Theoretical Model (Figure 1) of the Imaginative Construction of Care. This complex process comprises unknown realities, in view of the absence of the physical space. This demands the creation of a space of interaction, based on imaginative processes originating in the SELF, which allow one to enter a situation and discover the actors of the interaction with a view to a social construction of reality.

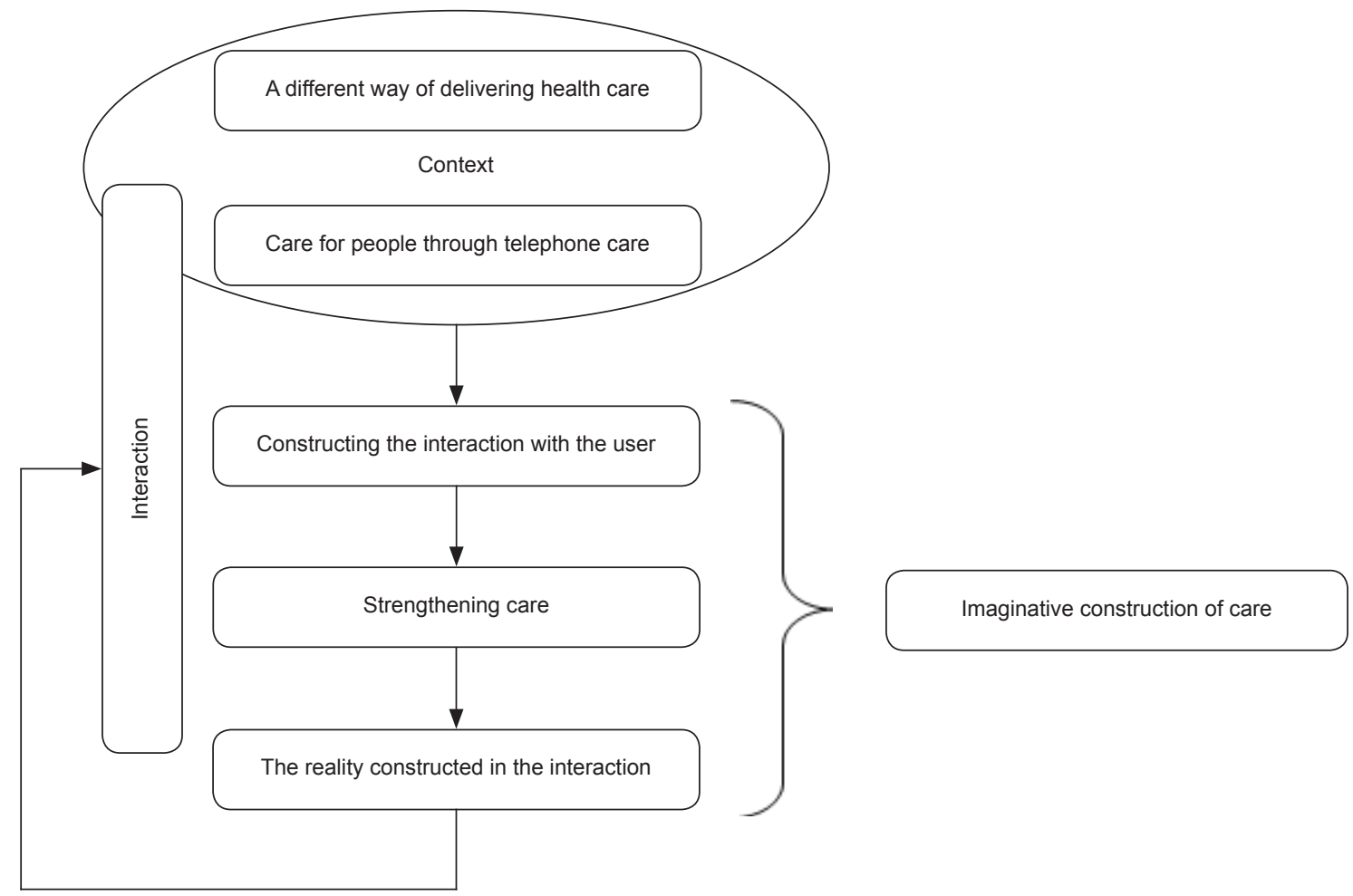

Figure 1 - The process of the Imaginative Construction of Care 
The Imaginative Construction of Care represents the strategies and actions Salud Responde professionals experience in care delivery to users and their families. Based on this model, a different way of delivering health care represents the entry into the situation where the professional's experience takes place. It is the acknowledgment of the context that grants a symbolic perspective.

It is based on the construction of the image of work that professionals construct their goal of delivering care to people through telephone care. This is a second condition involved in the start of the process, which implies an active search for symbols and signs, as well as their interpretation. This leads to a point where the professionals are already constructing the interaction with the user, which appears as a consequence of the previously established definitions and conditions.

This definition results from awareness about the objects and components of the situation, giving rise to the objective and concrete interpretation of the meanings that give sense to the entire experience.

To reach this interpretation, professionals interact permanently in the attempt to strengthen care. Professionals get closer to the reality constructed in the interaction; that is, this is a new reality, constructed through the interaction between professionals and users, which results from the Imaginative Construction of Care.

\section{Discussion}

The identified communication process comprises categories that are similar to other studies ${ }^{(4,11-12)}$. These highlight new communication skills and resulting challenges, so as to guarantee presence and support, which are essential for care. A single study presents a proposal to understand telenursing work ${ }^{(13)}$, underlining the categories of the studies that were indicated without going deeper into the relations among them. The theoretical model provides pertinent contributions to disciplinary knowledge, strengthening the identification of patterns and replacing care as a professional axis, mainly in its cultural and ethical components. The process described in this study confirms some categories found in other studies, but differs in how the categories are integrated as a theoretical model. Cultural sensitivity is highlighted in literature as the need to tell information about the cultures we deliver care to; a cultural competency(14). This study also permits taking into account what authors ${ }^{(15)}$ mention about the so- called human depth, sensitivity and compassion when interacting with the user. This sensitivity is a necessary skill for telephone care, as well as professionals' high level of self-knowledge.

One aspect of great symbolic meaning in this study, imaginative care, is indicated in studies that recognize imagination $^{(16-17)}$ as a part of the moral dimension of care, which permits professionals' sensitivity; it is acknowledged as a moral strategy to establish interaction with the patient. When understanding the process of life as a care system, one can understand that this is a form of coping with the situations one is exposed to, assuming that care can be learned, unlearned and relearned ${ }^{(18)}$. Thus, this relation implies getting involved in the other's reality, recurring to the imagination, which is only possible to the extent that the real is present and imagined. Thus, a cognitive and emotional connection is

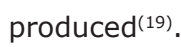

The sensitivity identified in our study is what allows professionals to understand the development of their know-how in relation to the vulnerability of human beings, also acknowledging the role of ethical sensitivity in the establishment of interaction with the user $^{(20)}$. The Imaginative Construction of Care implies the professionals' condition of coexisting at all times with uncertainty. Acts and symbols are also recognized though, which permit unveiling the professionals' responsibility for the construction of a new space of interaction ${ }^{(21)}$. Uncertainty ${ }^{(22)}$ is acknowledged as a part of clinical nursing practice, and mainly elaborated in further depth from the users' perspectives. The Imaginative Construction of Care results in the construction of a significant social network, which is critical to the promotion of wellbeing, the development of identity and the consolidation of potential changes(23). Finally, one needs to understand the way interaction is established between professionals and users in new spaces of practice like Salud Responde, which increasingly depends on skills to use new technologies(24), new communication patterns and authentic relations, reinforcing the role of public health nursing(25) as a trigger of collective care actions, permanently concerned with users' autonomy.

\section{Conclusion}

This model was described from the perspective of Chilean professionals, but provides significant elements as a contribution to understand the communication and care delivery process in remote care services. We can appoint two main aspects in terms of the implications for 
professional training; the first is mainly related to early phases of undergraduate education, and the second is the need for continuous professional training. The need to strengthen education in the ethical dimension of care is evidenced, besides communication and knowledge to understand individuals and families' psychosocial aspects. This is highlighted through the emphasis on the construction of interaction with users, which should result from a subjective experience of presence for both, although they are geographically distant. The Theoretical Model also permits acknowledging how professional autonomy finally occurs, in this unique meeting with the other, through a significant interactional relation, but which at the same time imposes the challenge of establishing evaluations from the perspective of other social actors, like the users. These study findings should be broadened to other contexts and countries and include the users' understanding. The Imaginative Construction of Care permitted the use of qualitative research methods, applying social theories like Symbolic Interactionism. This revealed new challenges fur future research development. From a more to public healthrelated perspective, it challenges us to continue creating care strategies that are significant to users.

\section{References}

1. Salud Responde Homepage [atualizado 20 mar 2011; acesso 20 mar 2011]. Disponivel em: http://www. saludresponde.cl/

2. Kuriakose JR. Telenursing an emerging field. Int J Nurs Educ. 2011;3(2):52-5.

3. Edirippulige S. Readness of nursing for practice telehealth. Studies Health Technol Informatics. 2010;161:49-56.

4. Ernesäter A, Holmström I, Engström M. Telenurses' experiences of working with computerized decision support: supporting, inhibiting and quality improving. J Adv Nurs. 2009;65(5):1074-83.

5. Tanner D. Starting with lives, supporting older people's strategies and ways of coping. J Social Work. 2007;7(1):7-30.

6. Xuanping S. Social Support and mortality among older persons with diabetes. Diabetes Educ. 2007;33:273.

7. Heitman LK. Social support and cardiovascular health promotion in families. J Cardiovasc Nurs. 2008 2004;19(1):86-91.

8. Charon J. Symbolic Interactionism: An Introduction, an Interpretation, an Integration. Pearson: Prentice Hall; 2004
9. Charmaz K. Constructing grounded theory: a practical guide through qualitative analysis. Thousand Oaks, CA: Sage, 2006

10. Ministerio de Salud ( $\mathrm{CH})$. Departamento de Asesoría Jurídica, Sobre La Investigación Científica En El Ser Humano, Su Genoma, Y Prohíbe La Clonación Humana, Ley No 20.120 Publicada en el Diario Oficial de 22 sept. 2006.

11. Sävenstedt S, Zingmark K, Sandman P-O. Being present in a distant room: aspects of teleconsultations with older people in a nursing home. Qual Health Res. 2004;14(8): 1046-57.

12. Rothwell E, Ellington L, Planalp S, Crouch B. Exploring challenges to telehealth communication by specialists in poison information. Qual Health Res. 2012;22(1):67-75. 13. Kaminsky E, Rosenqvist U, Holmström I. Telenurses' understanding of work: detective or educator? J Adv Nurs. 2009;65(2):382-90.

14. Taylor IG, Papadopoulos M, Maerten M, Z. Intercultura education of nurses and health professionals in Europe (IENE). Int Nurs Rev. 2011;58(2):188-95.

15. Palacios D. Implicaciones éticas del uso de la técnica y la tecnología en la aplicación de cuidados. Rev Cubana Enferm. 2008 [acesso 13 jan 2010]. 24(1). Disponível em: $\quad$ http://scielo.sld.cu/scielo.php?script=sci_ arttext\&pid=S0864-03192008000100007\&Ing=pt.

16. Scott P. Care, attention and imaginative identification in nursing practice. J Adv Nurs. 1995;22(6):1196-200.

17. Scott P. Imagination in practice. J Med Ethics. 1997;23(1):45-50.

18. Arber A, Gallagher A. Generosity and the moral imagination in the practice of teamwork. Nurs Ethics. 2009;16(6):775-85.

19. Lorenzini A. Bettinelli L. El Ser Humano y sus posibilidades de construcción desde el cuidado. Aquichan. 2003;3(1):48-51.

20. Weaver K. Ethical sensitivity: state of knowledge and needs for further research. Nurs Ethics. 2007; 14(2):141-55.

21. Matumoto S, Mishima SM, Fortuna CM, Pereira MJB, Almeida MCP de. Preparando la relación para atender al paciente: una herramienta para el acogimiento en unidades de salud. Rev. Latino-Am. Enfermagem. 2009;17(6):1001-8.

22. Vaismoradi, M. Salsali, M. Ahmadi, F. Nurses experience of uncertainty in clinical practice: a descriptive study. J Adv Nurs. 2010;67(5):991-9.

23. Souza MHN, Souza IEOT, Romijn F. La utilización del marco metodológico de red social en asistencia de 
enfermería a mujeres que amamantan. Rev. Latino-Am.

Enfermagem. 2009;17(3):354-60.

24. Nguyen DN, Zierler B, Nguyen HQ. A survey of nursing needs for training in use of new technologies for education and practice. J Nur Educ. 2011;50(4):181-9. 25. Fortuna CM, Matumoto S, Pereira MJB, Mishima SM, Kawata LS. El enfermero y las prácticas de cuidados colectivos en la estrategia: salud de la familia. Rev. Latino-Am. Enfermagem. 2011;19(3):581-8. 